УДК 551.3

DOI: 10.23671/VNC.2018.3.16552

\title{
MAPPING OF SOIL LIQUEFACTION POTENTIAL SUSCEPTIBILITY FOR URBAN AREAS
}

\author{
(c) 2018 G.P. Ganapathy'1, Associate Professor, Phd, \\ V.B. Zaalishvili², Sc. Doctor (Phyth.-Math.), Prof., \\ D.A. Mel'kov², Sc. Candidate (Tech.), B.V. Dzeranov², Sc. Candidate (Geol.-Min.), \\ S.S. Chandrasekaran ${ }^{3}$
}

${ }^{1}$ Centre for Disaster Mitigation and Management, Vellore Institute of Technology (VIT), Vellore, 632014, India, e-mail: seismogans@yahoo.com;

${ }^{2}$ Geophysical institute VSC RAS, Russia, 362002, RNO-Alania, Vladikavkaz, Markov Str., 93 a, e-mail: cgi_ras@mail.ru;

${ }^{3}$ School Civil Engineering, Vellore Institute of Technology (VIT), Vellore, 632014, India, e-mail: chandrasekaran.ss@ $@$ vit.ac.in,

Urban areas lying in the alluvial soil generally pose to threat of liquefaction even for moderate magnitude earthquakes. Liquefaction is the measure of vulnerability of saturated sediment to compact during earthquake shaking and thus generate pore water pressures sufficient to cause possible ground instability or failure. The buildings which are constructed over the liquefiable soil are more vulnerable during seismic shaking for a potential earthquake. The Chennai city of India is one of the most densely populated cities in the world, which consist of densely constructed high rise buildings in many parts. The city is under moderate seismic zone as classified by Bureau of Indian Standard where one can expected maximum magnitude of 6,9. The major part of the city covered by the Recent Alluvial soil with shallow water table, which is more vulnerable during earthquake shaking and quiet enough to trigger liquefaction. In this regard a study carried out to understand the liquefaction susceptibility of soil in the city using geotechnical parameters. Also the study reveals spatially $60 \%$ of the area is prone to liquefaction. Vladikavkaz city of Russia is also one of the most densely populated in the North Caucasus. Despite on the absence of historical data on liquefaction on this territory, there are soil conditions in new regions with a possible liquefaction behavior during strong earthquakes. Especially taking into account of Vladikavkaz seismic fault potential of $\mathrm{M}_{\max }=7,1$. In cooperation with Indian colleagues liquefaction susceptibility assessment method was adopted and applied for Vladikavkaz city. Seismic refraction survey is wide used in Russia rather than SPT and calculations were made on the basis size of shear velocity Vs. As a result $20 \%$ of the territory of Vladikavkaz city is liquefiable. The present study can be an eye opening for urban planners and decision makers and emergency responders for future developmental planning activity within the city.

Keywords: Liquefaction, Urban Areas, Chennai, Vladikavkaz, Susceptibility.

\subsection{Introduction}

The study of liquefaction of soil will be an important input to assess the seismic hazards in built-up areas. Liquefaction is one the most important seismic hazards which plays a major role in urban disasters. Since most of urban areas nowadays goes with construction of tall buildings due to space constrain. Soil liquefaction has been a major cause of damage to soil structures, lifeline facilities and building foundations in past earthquakes and clearly poses a significant threat to the integrity of structures and facilities during future earthquake (ISSMGE 1999). Buildings in zones of liquefaction are particularly vulnerable to differential ground movements, results from the heterogeneity of stratigraphy and soil properties (Bird et al., 2005). 
Globally many researches carried out studies on liquefaction assessment based on different methods [Youd and Hoose, 1977; Youd and Perkins, 1978; Iwasaki, 1982; Youd and Perkins, 1987; Obermeier, 1989; Power et al., 1992; Wakamastu, 1992; Susumu Yasuda, 2000; Bird and Bommer, 2004; Wakamatsu et al., 2006; El May et al., 2009; Holzer, 2008; Vipin and Sitharam 2009; Ganapathy and Rajawat, 2012]. The Chennai city, the capital of Tamil Nadu State in India is one of the highly densely populated city in the world which consist of 90 percent built up areas. Many of the buildings in Chennai are multistory, such the case safety of this city is extremely important for safeguarding human lives and property.

Vladikavkaz city, the capital of the North Ossetia-Alania Republic of Russian Federation, is also one of the most densely populated in the North Caucasus. Almost all the territory includes dense living and industrial building stock. Despite on the absence of historical data on liquefaction on this territory, there are soil conditions in new regions with a possible liquefaction behavior during strong earthquakes [Zaalishvili et al., 2016]. Especially taking into account of Vladikavkaz seismic fault potential of $\mathrm{M}_{\max }=7,1$ [Zaalishvili, Rogozhin, 2011].

The shallow geological subsurface provides a physical environment that provides people with the natural resources to extract (minerals, groundwater and ground source heat for example) and with which to deposit wastes. It also provides a medium to support the construction of engineered structures and the installation of below ground utilities and underground developments. Very few researchers carried out liquefaction studies for the Chennai city. Anbazhagan and Premalatha [2004] carried out liquefaction study using factor of safety based on SPT data of 15 locations. Ganapathy and Rajawat [2012] assessed the liquefaction potential of Chennai based on integrating the lithologic and geomorphologic characteristics. They have classified the city in to three zones viz, liquefaction likely, liquefaction possible, and liquefaction not likely. However the there is no detailed study on liquefaction susceptibility work done so far for the city. The present study aims to produce liquefaction susceptibility map in the built up areas of Chennai city, India.
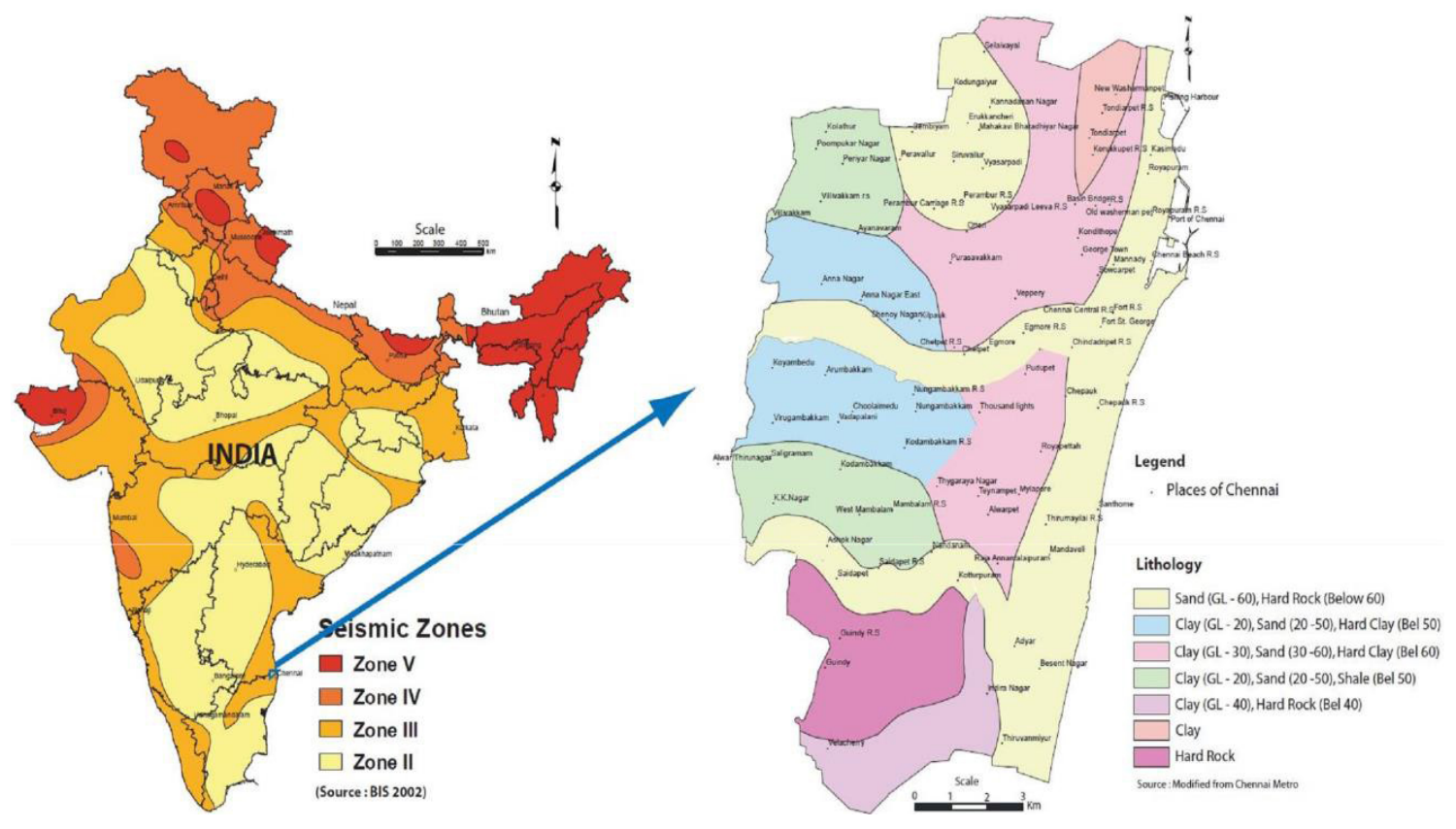

Fig. 1. Location map of the Study area over a) Seismic Hazard and b) Lithological distribution Map 


\subsection{Study Area and its Baseline Information}

\subsection{Lithology}

The Archaean crystalline rocks, Gondwana \& Tertiary sediments and Recent alluvium are the three group of geological formations are found in Chennai. [CGWB Report, 1993]. The subsurface lithology of Chennai broadly grouped in to seven unit's viz. Hard rock, clay formation, clay over hard rock, clay - sand - shale formations, clayey sand - sand - hard rock, clay-sand-hard rock, and sand over hard rock. The south western part of the city is covered by hard rock of Charnockites. The outcrops exposed over few meters in St. Thomas mount area near Guindy as residual hills (Figure 1).

\subsection{Depth to water table and water level fluctuation}

Liquefaction has been most abundant in areas where ground water lies within $10 \mathrm{~m}$ of the ground surface; few instances of liquefaction have occurred in areas with ground water deeper than $20 \mathrm{~m}$. The depth to ground water level in the city varies from 2 to $8 \mathrm{~m}$ in the city. The long-term water level fluctuation for the period from 1998 to 2007 indicates rise in water level in the area at the rate of $0,00300,93 \mathrm{~m} /$ year. The fall in water level ranges between 0,037 and $0,798 \mathrm{~m} /$ year (CGWB, 2008).

For Vladikavkaz city the ground water level is about $80-100 \mathrm{~m}$, while there some watered sites caused by clay permeability barriers. This is due to the fact that the territory of the city is represented by terraces of the river Terek, formed by powerful pebbles (up to $500 \mathrm{~m}$ ), mostly with a sandy aggregate, which is transmitting water well.

\subsection{Geomorphology}

Chennai district forms part of coastal plains and major part of the having flat topography with very gentle slope towards east. The land elevation varies from $10 \mathrm{~m}$ above MSL in the west to sea level in the east. Fluvial, marine and erosional landforms are noticed in the district. Marine transgression and regressions and neo-tectonic activity during the recent past have influenced the morphology and resulted in various present landforms [GSI, 2005 and CGWB, 2008].

Almost the entire territory Vladikavkaz city is also formed flat topography with very gentle slope towards west (old part of the city, Butyrina street, etc.), with the exception of one site in the southern part of the city with an inclination angle of more than 15 degrees, extending along the river Terek. [Zaalishvili et al., 2011].

\subsection{Seismic hazard assessment}

The earthquake magnitude is an important parameter to trigger the liquefaction. The Chennai city has been classified under Zone III (moderate seismic hazard - Magnitude 6,9 ) as per seismic hazard map of India published by Bureau of Indian Standard (BIS, 2001). Further the city broadly classified into three zones, as high, moderate and low in terms of seismic hazard in an event of future earthquakes. The part of Chennai falls in seismically moderate to high hazard prone areas [Ganapathy, 2011, Ganapathy and Rajarathnam, 2009]. The expected maximum Magnitude 6,9 is quite good enough to liquefy the soils of Chennai.

Vladikavkaz seismic fault, directly located in the southern part of the city is characterized by the high seismic potential of $\mathrm{M}_{\max }=7,1$ [Zaalishvili, Rogozhin, 2011]. 


\subsection{Methodology}

The zoning of soil liquefaction potential can be done in various methods like i) based on pre existing data from available published resources, ii) estimation of liquefaction susceptibility based on existing data viz., Geological \& geomorphological criteria and Liquefaction Severity Index (LSI), in-situ liquefaction susceptibility based on Standard Penetration Test and Cone Penetration Test [ISSMGE, 1999 and Bhandari, 2002]. In the present study a simple approach used to calculate the factor of safety in term of liquefaction susceptibility by using geotechnical details from the Standard Penetration Test (SPT) boreholes. The methodology used for the present study is given in Figure 2.

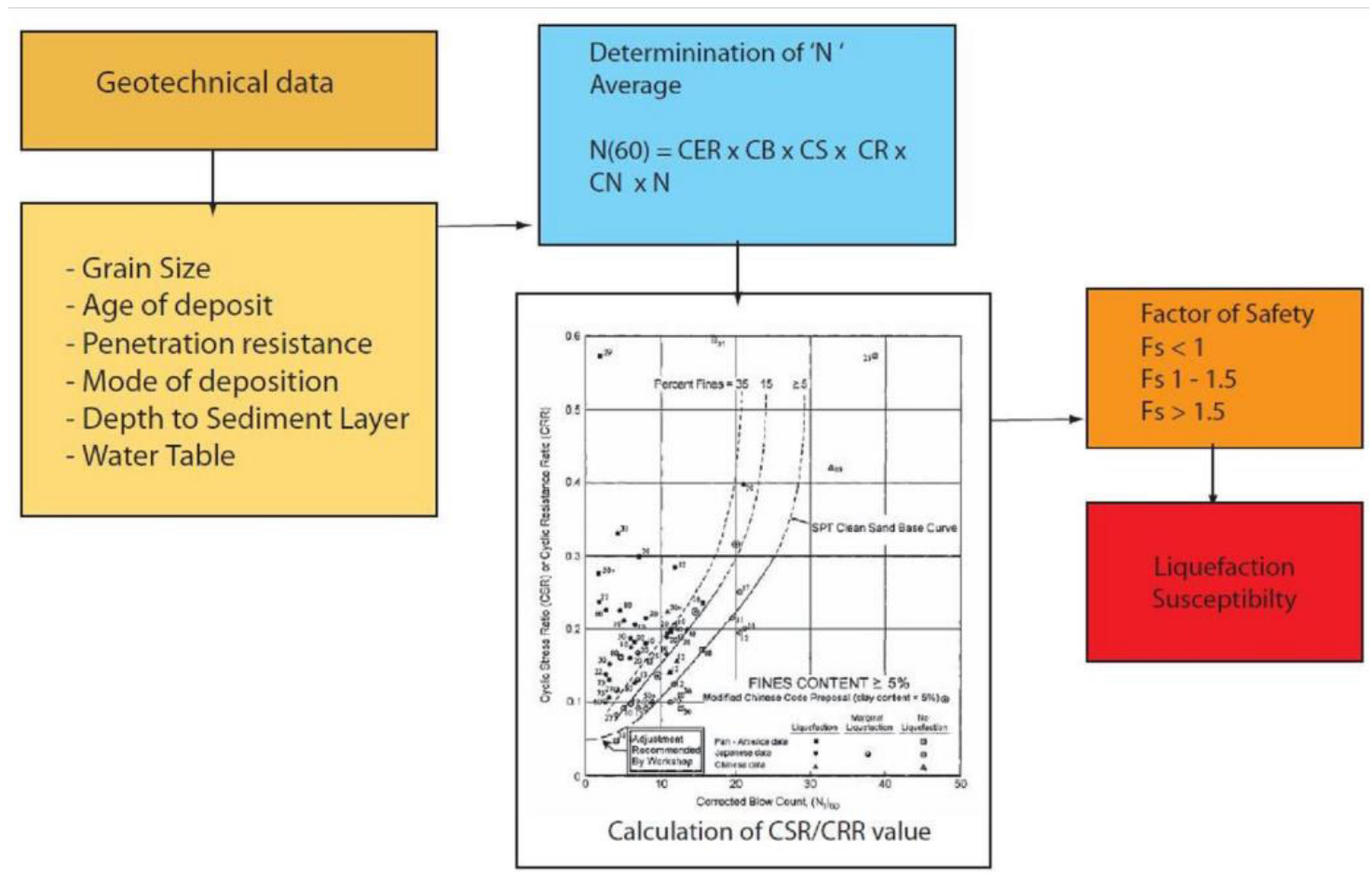

Fig. 2. Methodology used to produce liquefaction Susceptibility Map

\subsection{Estimation of Liquefaction Susceptibility}

To attain the liquefaction susceptibility map of Chennai geotechnical data were collected from different authenticated source and used for the present study. Totally 45 boreholes collected and the parameters viz, grain size, effective stress, water table, soil layers, depth were studies and the SPT 'N' value.

Various corrections were made to synthesize the SPT data (using eq.1) and the N average for $4 \mathrm{~m}$ depth is calculated. (N) 60 is the $\mathrm{N}$ value corrected for the field procedures to an average energy ratio of 60 per cent.

$$
\text { (N) } 60=\mathrm{CER} * \mathrm{CB}^{*} \mathrm{CS}^{*} \mathrm{CR}^{*} \mathrm{CN}^{*} * \mathrm{~N}
$$

Where CER is Energy ratio correction, $\mathrm{CB} \quad$ Borehole diameter correction, $\mathrm{CS}$ Sampling method correction, CR Rod length correction, N Measured SPT 'N' Value blows / $30 \mathrm{~cm}, \mathrm{CN}$ overburden stress correction factor. (N)60 value was used to find CRR from energy ratio curve. 
Then the average $(\mathrm{N}) 60$ values are obtained for each borehole. The average $\mathrm{N}$ value for $4 \mathrm{~m}$ depth were plotted in GIS platform and given in Figure 3. CRR values are taken from the standard graph as per the values of $(\mathrm{N}) 60$.
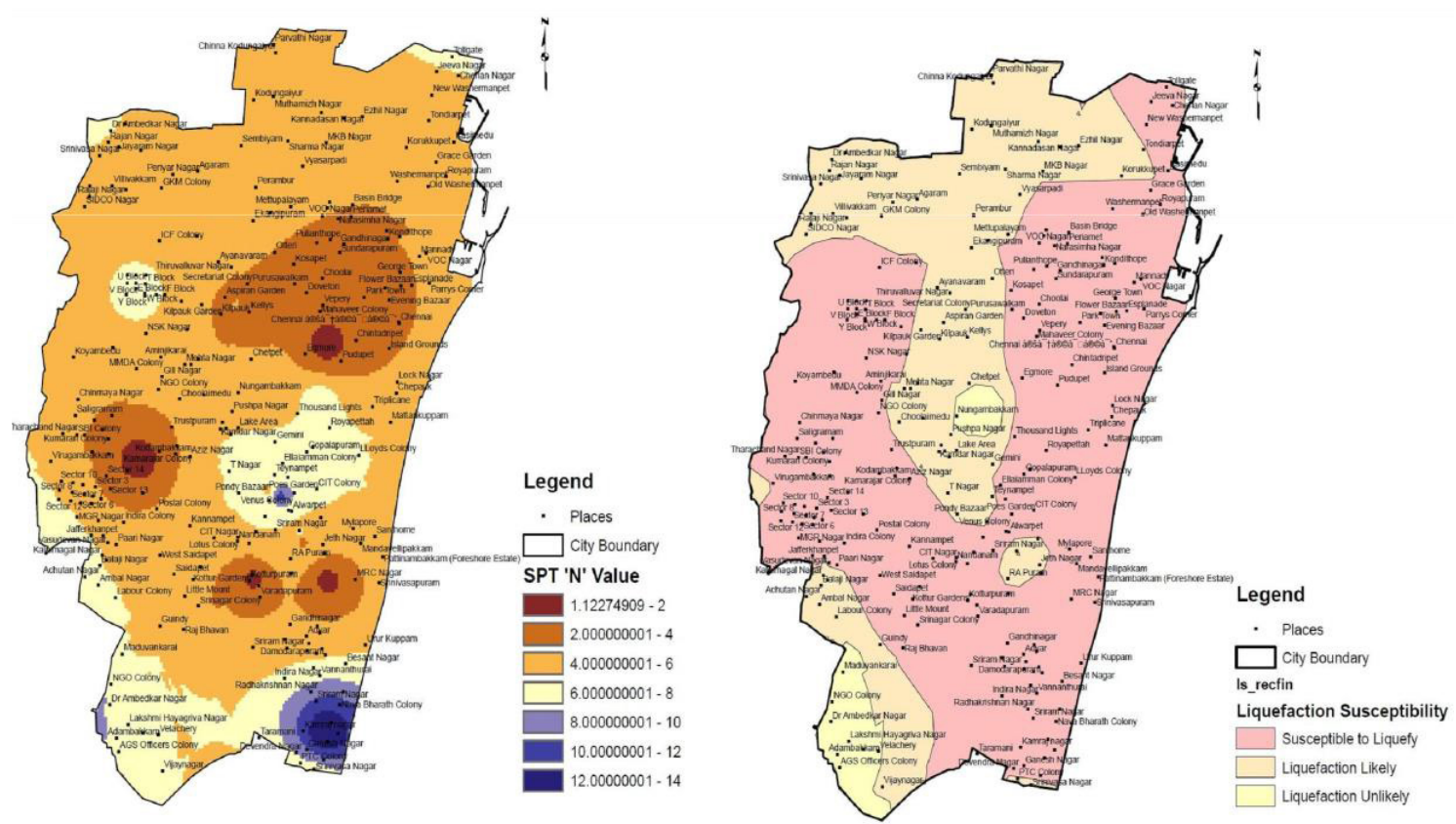

Fig. 3. Spatial Distribution of SPT 'N' Value. Fig. 4. Liquefaction Susceptibility map of Chennai City

Standard Penetration Test (SPT) is not commonly used in Russia. For Vladikavkaz city factor of safety was calculated on the basis of shear wave velocity Vs. The use of $\mathrm{Vs}$ as a field index of liquefaction resistance is justified because both $\mathrm{V}_{\mathrm{S}}$ and CRR are similarly influenced by void ratio, effective confining stresses, stress history and geologic age [Youd, Idriss, I. M., 1997]. One of the most advantages is that $V_{S}$ measurements are possible in soils that are difficult to penetrate with CPT and SPT, or to extract undisturbed samples, such as gravelly soils.

CRR ratio were calculated by Andrus and Stokoe approach:

$$
C R R=0.03\left(V_{S l} / 100\right)^{2}+0.9 /\left(V_{S l c}-V_{S l}\right)-0.9 / V_{S l c},
$$

Where $V_{S l}$ is normalized $V_{S}$ by Robertson et al. (1992):

$$
V_{S l}=V_{S}\left(P_{a} / \sigma_{v o}^{\prime}\right)^{0.25}
$$

$\mathrm{V}_{\mathrm{Slc}}$ - critical value of $\mathrm{V}_{\mathrm{Sl}}$, which separates contractive and dilative behavior of granular soils at large strains.

For magnitude 7,5 earthquakes Andrus and Stokoe determined the following best-fit values for $\mathrm{V}_{\mathrm{Slc}}$ :

$\mathrm{V}_{\mathrm{Slc}}=220 \mathrm{~m} / \mathrm{s}$ for sands and gravels with fines contents less than $5 \%$,

$\mathrm{V}_{\mathrm{Slc}}=210 \mathrm{~m} / \mathrm{s}$ for sands and gravels with fines contents of about $20 \%$,

$\mathrm{V}_{\mathrm{Slc}}=200 \mathrm{~m} / \mathrm{s}$ for sands and gravels with fines contents greater than $35 \%$.

The uniform cyclic shear stress amplitude for level (or gently sloping) sites can also be estimated from a The simplified procedure [Seed and Idriss, 1971] used from eq 2. 


$$
\mathrm{CSR}=0,65\left(\mathrm{a}_{\mathrm{MAX}} / \mathrm{g}\right)\left(\sigma_{\mathrm{VO}} / \sigma_{\mathrm{VO}}\right) \mathrm{r}_{\mathrm{d}}
$$

where amax - peak ground horizontal acceleration at the surface generated by earthquake.

$\sigma_{\mathrm{VO}}, \sigma_{\mathrm{VO}},-$ total and effective vertical stresses

$r_{d}=$ stress reduction coefficient, which is a function of depth and rigidity of soil column

$$
\begin{array}{ll}
=1,0-0,00765 \mathrm{z}, & \text { for } \mathrm{z}<=9,15 \mathrm{~m} \\
=1,174-0,0267 \mathrm{z} & \text { for } 9,15 \mathrm{~m}<\mathrm{z}<=23 \mathrm{~m}
\end{array}
$$

$\mathrm{z}=$ depth below ground surface in meters

For Chennai $\mathrm{a}_{\max }=0,37 \mathrm{~g}$ value was used. For Vladikavkaz $\mathrm{a}_{\max }=0,4 \mathrm{~g}$, which is corresponds to intensity of 9 in MSK 64 scale [Zaalishvili et al., 2018].

The Factor of safety is calculated using CSR, CRR and MSF values. The factor of safety values ranging from 0,1 to 2,5 for the study area. The Factor of safety classified in to three categories viz., 0 to $<1,1$ to 1,5 , and $>1,5$ based on the Susceptibility to liquefaction of the Soil. The values 0 to $<1$ means the soils are highly susceptible to liquefy, 1 to 1,5 means liquefaction may be likelihood chances and $>1,5$ will be no chance of liquefaction of soil for the magnitude 6,9 for $4 \mathrm{~m}$ depth. The factor of safety values are used in Spatial analyst tool to prepare the Liquefaction susceptibility map for Chennai city and presented in Figure 4.

Example of factor of safety calculation for one of the sites in Vladikavkaz city is presented in figure 5 and result liquefaction susceptibility map of Vladikavkaz City in figure 6 . As a result $20 \%$ of the territory of Vladikavkaz city is liquefiable.

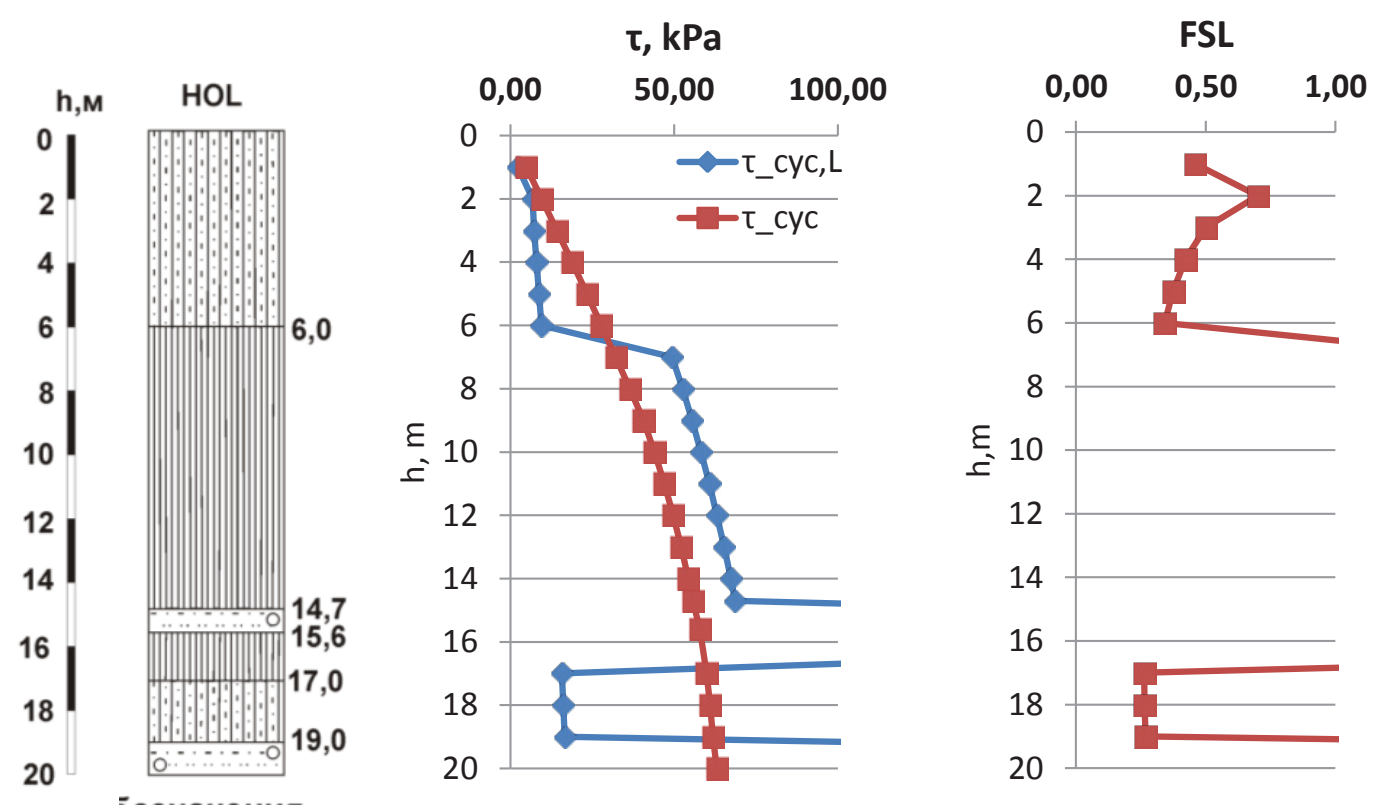

Fig. 5 Example of the factor of safety calculation for HOL seismic station soil conditions, Vladikavkaz city 


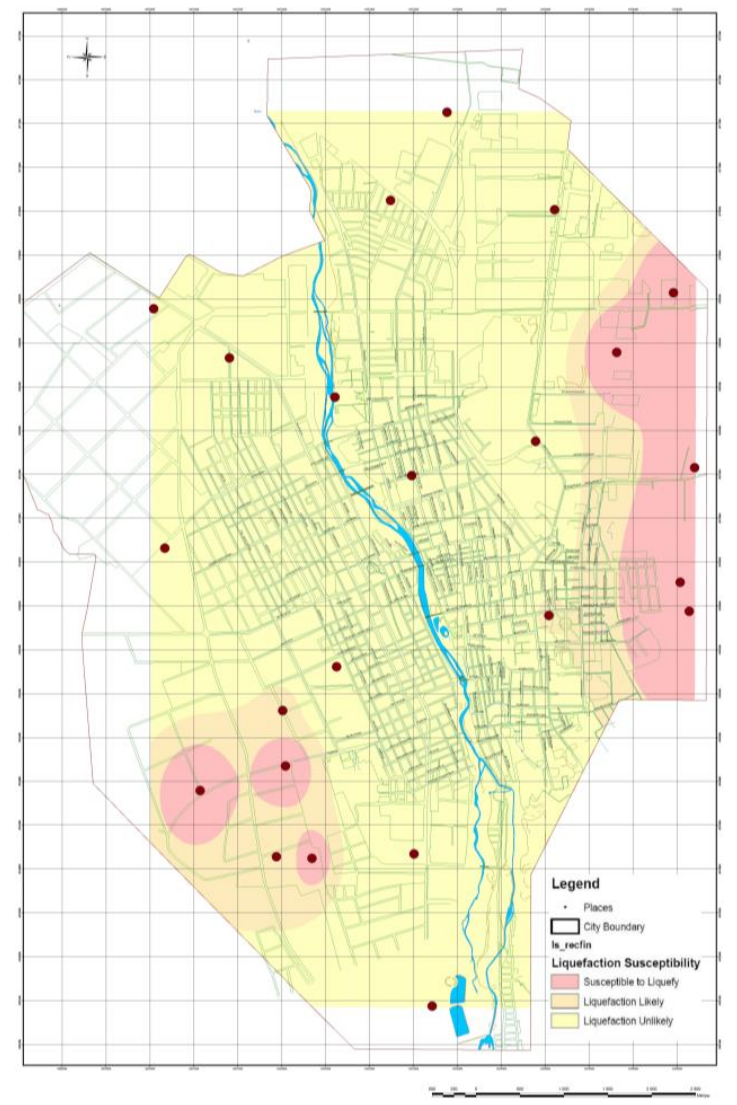

Fig. 6. Liquefaction Susceptibility map of Vladikavkaz City

\subsection{Conclusions}

Based on the analysis the areas are divided in to three zones of Liquefaction susceptibility viz., Susceptible to liquefy, Liquefaction Likely and Liquefaction unlikely (Totally 45 SPT boreholes were selected to understand the subsurface soil characteristics of the Chennai city). The present study is based in a hypothetical earthquake magnitude of 6,9 (for moderate seismic Zone) and the scenario of liquefaction will be different for the different magnitude earthquakes. Also the present study purely based on available data collected from different sources and it is only spatially covered the area, however the liquefaction Susceptible map will be change if more number of data used with minor geological information's. The present study can be used as first hand information for planning new settlements, lifeline structure for future development within the city. Also its need the tall buildings within the Liquefaction Susceptible areas are should have detailed site specific study for safety of the buildings.

\section{References}

1. Anbazhagan P, Premalatha K (2004) Microzonation of liquefaction factor of safety of Chennai city. Journal of Indian Geotechnical Congress: pp. 227-230.

2. Bhandari R.K Rajarathnam S, Janardhanan G, Ganapathy, G.P (2003) Seismic Microzonation, Monographv published by Centre for Disaster Mitigation and Management, Anna University, Chennai, 142 p.

3. Bird, J.F., Bommer, J.J. (2004) Earthquake losses due to ground failure. Eng. Geol 75, 2nd Edition: pp. 147-179. 
4. Bird J.F., Crowley H., Rui Pinho, Julian J. Bommer (2005), Assessment of building response to liquefaction induced differential ground deformation, Bulletin of the New Zealand Society for Earthquake engineering, Vol. 38. No.4, December 2005, pp. 215-226.

5. BIS: 1893 (2001) Criteria for earthquake resistant design of structures. Bureau of Indian Standards, New Delhi.

6. CGWB Report (1993) Groundwater resources and development prospects in Madras district. Tamil Nadu, Central Ground Water Board, Southern Region, Hyderabad

7. CGWB (2008) District groundwater brochure Chennai district Tamil Nadu, Technical report Series Central Ground Water Board South Eastern Coastal Region, Chennai, November 2008, pp. 19.

8. Craig V. Nelson (2002) Liquefaction: A guide to land use planning, Geological Hazards Ordinance - Chapter 19.75, Appendix B, 6, 2002.

9. Ganapathy G.P. (2011), First level seismic microzonation map of Chennai city - a GIS approach, International Journal - Natural Hazards and Earth System Sciences, No. 11 , pp. 549-559.

10. Ganapathy G.P. and Rajawat A.S (2012), Evaluation of Liquefaction Potential Hazard of Chennai City, India, Using Geological and Geomorphological Characteristics, International Journal - Springer - Natural Hazards, Journal of the International Society for the Prevention and Mitigation of Natural Hazards ISSN: 1573-0840, DOI 10.1007/s11069-012-0331-1, Vol.64, pp. 1717-1729.

11. Ganapathy G.P and Rajarathnam S (2009), Site Response Study for Urban Areas of Chennai City, India - A Geotechnical Approach, IS Tokyo 2009, Performance-Based Design in Earthquake Geotechnical Engineering - Case History to Practice - Kokusho, Tsukamoto \& Yoshimine (eds) (C) 2009 Taylor \& Francis Group, London, ISBN 978-0415-55614-9, pp. 365-371.

12. GSI (2005) District resource map of Chennai, published by Geological Survey of India (GSI), Hyederabad.

13.ISSMGE (1999), manual for Zonation on Seismic Geotechnical Hazards (Revised Version), Technical Committee for Earthquake Geotechnical Engineering, TC4, ISSMGE, ISBN 4 88644-809-7, Published by The Japanese Geotechnical Society, Tokyo, Japan, pp. 210.

14. Iwasaki, T., (1982) Microzonation for soil liquefaction potential using simplified methods, in: Proceedings of the 3rd International Conference on Microzonation, Seattle, 3: pp. 1310-1330.

15. Obermeier, S.F. (1989) The New Madrid earthquakes: An engineering-geologic interpretation of relict liquefaction features, U.S. Geological Survey Professional Paper 1336-B: $114 \mathrm{p}$.

16. Power, M.S., J.W. Wesling, R.C. Perman, R.R. Youngs, and L.A. DiSilvestro, (1992) Evaluation of liquefaction potential in San Jose, California, Report to U.S. Geological Survey, Award No. 14-08-0001-G1359, by Geomatrix Consultants, San Francisco, California.

17. Seed, H.B., and Idriss, I.M. (1971). "Simplified procedure for evaluating soil liquefaction potential.” J. Geotech. Engrg. Div., ASCE, 97(9), pp. 1249-1273

18. Susumu Yasuda (2000) Collection of surface data for the prediction of liquefaction potential (Partially quoted from the papers by Ishihara and Yasuda (1991) and TC4 (1999). 
19. Wakamatsu, K (1992) Evaluation of liquefaction susceptibility based on detailed geomorphological classification, in: Proceedings: Technical papers of annual meeting architectural institute of Japan, B: pp. 1443-1444

20. Youd T.L. and Perkins D.M (1987) Mapping of Liquefaction Severity Index, J.GED, ASCE, Vol. 113 : 11: pp. 1374-1392.

21. Youd, T.L. and Hoose, S.N. (1977) Liquefaction susceptibility and geologic setting, in: Proc. 6th World Conf. on Earthquake Engineering, New Delhi, 6: pp. 37-42

22. Youd, T. L. and Perkins, D. M (1978) Mapping liquefaction-induced ground failure potential, J. Geotech. Eng. Div., ASCE, 104: pp. 433-446.

23. Youd, T.L., and Idriss, I.M., eds. (1997). Proc., NCEER Workshop on Evaluation of Liquefaction Resistance of Soils, Nat. Ctr. for Earthquake Engrg. Res., State Univ. of New York at Buffalo. Technical Report NCEER-97-0022.

24.Zaalisvili V.B., Rogozhin E.A. (2011) Assessment of Seismic Hazard of Territory on Basis of Modern Methods of Detailed Zoning and Seismic Microzonation. The Open Construction and Building Technology Journal. Vol. 5. 11 p.

25.Zaalishvili V.B., Melkov D.A., Burdzieva O.G., Dzeranov B.V., Gabeeva I.L., A.S., Dzeranov B.V., Shepelev V.D., Gabaraev A.F. (2012) Seismic microzonation of Vladikavkaz city: historical review and modern techniques. Proceedings of 15th World Conference on Earthquake Engineering, Lisbon, Portugal, 10 p.

26.Zaalishvili V.B., Melkov D.A., Kanukov A.S., Dzeranov B.V., Shepelev V.D. (2016) Application of microseismic and calculational techniques in engineering-geological zonation. International Journal of GEOMATE. 2016. Vol. 10. No 1, pp. 1670-1674.

27.Zaalishvili V.B., Melkov D.A., Dzeranov B.V., Burdzieva O.G. (2018) Complex probabilistic seismic hazard assessment: North Ossetia-Alania case study. 16th European Conference on Earthquake Engineering conference proceedings. 11 p.

DOI: 10.23671/VNC.2018.3.16552

\section{КАРТИРОВАНИЕ ПОТЕНЦИАЛА ВОЗМОЖНОГО РАЗЖИЖЕНИЯ ГРУНТОВ ДЛЯ УРБАНИЗИРОВАННЫХ ТЕРРИТОРИЙ}

\footnotetext{
() 2018 Г.П. Ганапатхиㄹ, профр., В.Б. Заалишвили², д.ф.-м.н., профр., Д.А. Мельков ${ }^{2}$, К.т.н., Б.В. Дзеранов², к.г.-М.н., С.С. Чандрашекаран ${ }^{3}$

1 Центр по смягчению и управлению стихийными бедствиями, Технологический институт Веллора, Индия, 632014, Веллори,e-mail: seismogans@yahoo.com;

2 Геофизический институт - филиал ФГБУН ФНЦ «Владикавказский научный центр Российской академии наук», Россия, 362002, РСО-Алания, г. Владикавказ, ул. Маркова, 93a, e-mail: cgi_ras@mail.ru;

${ }^{3}$ Школа гражданского строительства, Технологический институт Веллора, Индия, 632014, Веллори,e-mail: chandrasekaran.ss@ vit.ac.in
}

Урбанизированные территории, сложенные аллювиальными грунтами, характеризуются уязвимостью к их разжижению даже при землетрясениях средней величины. Разжижение является мерой склонности водонасыщенных отложений к уплотнению во время землетрясения и, таким образом, создает 
давление поровой воды, достаточное для возможной нестабильности грунта или его разрушения. Здания, построенные на подобных разжижаемых грунтах, весьма уязвимы при колебаниях, обусловленных землетрясением. Город Ченнаи в Индии является одним из самых густонаселенных городов в мире. Застройка, на его большей части, состоит из тесно расположенных высотных зданий. Город находится в пределах умеренной сейсмической зоны и по классификации Бюро Индийского стандарта здесь можно ожидать максимальную величину землетрясения с магнитудой 6,9. Большая часть города, покрытая молодыми аллювиальными грунтами с неглубоким уровнем грунтовых вод, весьма уязвимая при землетрясении, никак не выделяется по внешним признакам. В связи с этим для оценки подверженности грунтов разжижению, в городе проведены исследования на основе изучения геотехнических параметров. Результаты исследования показывают, что более $60 \%$ территории городской площади Ченнаи подвержено разжижению. Город Владикавказ в России - один из наиболее плотно населенных городов на Северном Кавказе. Несмотря на отсутствие исторических данных по разжижению грунтов на этой территории, относительно недавно урбанизированной (по крайней мере, в 1810 г.), здесь присутствуют грунты с возможным проявлением явления разжижения при сильных землетрясениях. При этом необходимо учитывать, что непосредственно в южной части города расположен Владикавказский разлом с ожидаемым сейсмическим потенциалом $\mathrm{M}_{\max }=7,1$. В сотрудничестве с индийскими коллегами метод оценки подверженности грунтов разжижению был адаптирован и применен для территории г. Владикавказа. В то же время в отличие от метода пенетрации (SPT), при исследованиях грунтов Владикавказа использовался более традиционный для России подход, и расчеты были сделаны на основе учета величины скоростей поперечных волн в грунтах. В результате расчетов было установлено, что почти 20\% территории города Владикавказа сложено грунтами, подверженных разжижению.

Настоящее исследование может заставить градостроительные службы и лиц, принимающих решения, а также аварийно-спасательные службы в их будущей деятельности по планированию развития городских территорий уделять большее внимание подверженности грунтов разжижению.

Ключевые слова: разжижение, урбанизированные территории, Ченнаи, Владикавказ, подверженность. 